Full length article

\title{
Factors that explain the use of ICT in secondary-education classrooms: The role of teacher characteristics and school infrastructure
}

\author{
Javier Gil-Flores, Javier Rodríguez-Santero, Juan-Jesús Torres-Gordillo* \\ Department of Educational Research Methods and Diagnostics, Office 4.52, Educational Sciences Faculty, University of Seville, Pirotecnia Street, 41013 \\ Seville, Spain
}

\section{A R T I C L E I N F O}

\section{Article history:}

Received 27 August 2016

Received in revised form

22 November 2016

Accepted 28 November 2016

Available online 9 December 2016

\section{Keywords:}

Media in education

Teaching/learning strategies

Secondary education

Pedagogical issues

Improving classroom teaching

\begin{abstract}
A B S T R A C T
Paradoxically, in Spain, schools have relatively ample information and communication technology (ICT) infrastructure but low levels of classroom ICT use. In this study, we analyse the role of school ICT infrastructure and teacher characteristics to explain ICT use in education. We use data from the Spanish sample in the 2013 Teaching and Learning International Study (TALIS), which consists of 3339 teachers from 192 secondary education centres. The analysis was conducted using multilevel logistic regression models. The principal results indicate that the availability of educational software, teacher ICT training, collaboration among teachers, perceived self-efficacy, and teaching concepts influence classroom ICT use. School hardware and internet-connection infrastructure are less significant. Based on the findings, recommendations are presented to orient Spanish educational policy to encourage the use of ICT in classrooms.
\end{abstract}

(C) 2016 Elsevier Ltd. All rights reserved.

\section{Introduction}

Educational systems worldwide aim to develop the digital competency of students. Thus, the curriculum developed in educational centres has included the acquisition of skills in using technology to discover, evaluate, store, produce, present, and exchange information. In addition to being an object of study, information and communications technology (ICT) has been gaining ground as a learning tool. Many educational systems have sought to increase the availability of computers and internet connections in classrooms. This equipment is an efficient tool for study, a valuable source of information, and an interesting support for teaching (Tondeur, van Braak, \& Valcke, 2007). Software programs designed for editing texts, creating graphs, organizing data, and completing calculations are useful tools for students. An internet connection makes it possible to access information and resources available on platforms designed for educational purposes. Additionally, opportunities are emerging to complement in-person teaching with virtual teaching thanks to the availability of software that simplifies the presentation of content, the performance of various activities,

\footnotetext{
* Corresponding author.

E-mail addresses: jflores@us.es (J. Gil-Flores), jarosa@us.es (J. RodríguezSantero), juanj@us.es (J.-J. Torres-Gordillo).
}

and providing students with feedback and that accommodates interaction between students and teachers.

Generally, ICT use by teachers can be divided into two levels (Van Braak, Tondeur, \& Valcke, 2004). The first level involves relatively ineffective use, such as basic support for teachers, which most often involves use in class preparation. The second level is effective use, which involves the use of ICT as an educational resource in the teacher's daily work with students. In this connection, Eng (2005) observes that introducing ICT into educational centres occurs in three phases. The first (emerging) phase involves amassing infrastructure. In the second (application) phase, teachers apply technology in the same teaching-learning processes that they have always used. In the third (infusion phase), teachers start to use technology in different ways in innovative pedagogies.

The provision of equipment and infrastructure has been the starting point of ICT policies that have been developed in national contexts. In recent years, some countries have developed specific programmes for the provision of ICT infrastructures to schools, as in the case of Spain (the 2.0 School Program), Hungary (The Digital School Plan), Italy (The Intelligent School Program), and Turkey (the FATIH Project). This provision was also extended to the homes of students from low-income families, as in the United Kingdom and Singapore (the Home Access Program). According to the report drafted by Vacchieri (2013), initiatives in this regard have been the general trend of ICT policies in countries both inside and outside 
Europe, but they have adopted different strategies. Although Hungary, the Czech Republic, Portugal, Germany, Estonia and Italy provide grants to schools or even classes that meet certain requirements, other countries such as Spain, the United Kingdom, the USA and Singapore have attempted to cover all schools. In a third case, countries such as France, Italy, Malta, Poland, Portugal and Israel, the Ministry of Education, in collaboration with private companies, grants incentives so that students or families acquire netbooks and, in some cases, broadband connectivity.

Regarding ICT integration into the curriculum, most countries have a curriculum framework that specifies general guidelines for ICT. These guidelines are established in different regions, localities, states, communities and, in some cases, even schools (Ireland). Only in countries such as Cyprus and Turkey is the curriculum entirely defined by the Ministry of Education. When focusing on the ICT competency that students must achieve, the actions of countries such as the United Kingdom, Italy, Norway, Belgium, Austria, Hungary and the Czech Republic should be emphasized. In these countries, the targets of this type of competency are widely specified. In other European countries, these targets are set in much more general terms.

In focusing on the Spanish context where this study was conducted, the policies that were developed for the implementation of ICT in education were, in their initial period (in the 1980s), promoted by the central government through the Athena Program, which was later known as the National Program for Information and Communications Technology. This program involved incorporating subjects related to computer science into the curriculum, providing schools with computers for administrative purposes (e.g., enrolment, grading, record keeping), and the first attempts at training teachers in ICT use. During the 1990s and until 2009, each autonomous community developed its own initiatives (e.g., constructing computer rooms in schools, training teachers, producing digital educational materials). All that the initiative had in common was that they were funded by the central government (Meneses, Fàbregues, Jacovkis, \& Rodríguez-Gómez, 2014).

It was not until 2009-2012 that thanks to the 2.0 School Program a true nationwide policy was established under which the various autonomous communities promoted similar goals and activities. These activities focused on providing classrooms the largest possible amount of equipment under the auspices of the model known as One-to-One, also referred to as One Laptop Per Child. Subsequently, decentralization occurred in parallel with budget cuts, which resulted in individual and diverging activities in different autonomous communities (Area et al., 2014). We refer to the use of digital platforms with educational content, tablets, wireless technology, digital blackboards, bring your own device (BYOD) models, blogs, and wikis and the creation of virtual classrooms.

There has been considerable evolution in the computing equipment provided for teaching and learning activities in Spanish secondary schools. In just over a decade, the average number of students per computer has decreased from 12 (2002-2003 school year) to three (2013-2014 school year) (INE, 2014). According to European Commission (2013), Spain occupied third place in a European ranking for this indicator, and the nation stands out for having nearly all schools online via a relatively fast broadband network. Additionally, $82 \%$ of schools have a website and virtual learning space, a statistic that clearly surpasses the median of $61 \%$ observed for EU countries.

Despite the high levels of equipment and broadband access, Spain is below the median for European countries with respect to ICT use in classrooms. Specifically, it is one of the five countries with the lowest percentage of such use. Only $52 \%$ of grade eight Spanish students declared using a school computer for learning purposes during lessons at least weekly (European Commission, 2013, p. 61). The results obtained for Spanish secondary-school teachers who participated in the 2013 Teaching and Learning International Study (TALIS) are similar. A total of $19.6 \%$ of these teachers stated that they never or nearly never use ICT in classroom teaching, and $43.4 \%$ stated that they do so only occasionally.

In short, we have established a low usage rate for computer resources in Spanish secondary schools. However, the availability of ICT infrastructure is high, and the Education Administration has developed policies directed at incorporating ICT into teaching. This paradoxical situation makes the Spanish case particularly interesting. In an effort to increase understanding of this issue, this study presents an analysis of variables associated with ICT use in secondary-education classrooms in Spain using country data from TALIS 2013.

\subsection{Factors associated with ICT use}

Computer-equipment availability (Akbulut, Kesim, \& Odabasi, 2007; Lee, 2002; Tallent-Runnels et al., 2006), student-to-teacher ratio (Erdogdu \& Erdogdu, 2015), school leadership (Suárez, Almerich, Orellana, \& Belloch, 2012) and presence of ICT in the curriculum (Akbulut, 2009) are the school-related variables that have been studied because of their potential implications for the introduction of ICT into classrooms. Study results indicate that the effect of these variables is small, particularly compared with other factors, such as openness to change and appropriate school policies (Tondeur, Valcke, \& van Braak, 2008). Similarly, Pelgrum and Voogt (2009) cite the need for leadership in educational centres that encourages in teachers a desire to use new ICT-based teaching methods, the acquisition of higher levels of ICT competency, and the development of a collaborative culture that promotes the introduction of ICT into the teaching and learning process. In this regard, Akbulut (2009) also indicates that Learning Community Policies are factors that are associated with ICT use.

Regarding teachers, the characteristics that are associated with ICT use include experience, the grade that is taught, age, gender (Suárez et al., 2012; Tondeur et al., 2008; Wong \& Li, 2008) and academic department (Akbulut, 2009). Use appears to be greater among male teachers who are relatively young (Scherer, Siddiq, \& Teo, 2015) and who teach the highest grades, although the effect of these variables is small and only statistically significant in the cases of age (Scherer et al., 2015) and gender (Suárez et al., 2012; Van Braak, 2001). Other noteworthy traits include teachers' commitment and skill (Ertmer, Ottenbreit-Leftwich, \& York, 2007; Fraizer \& Bailey, 2004; Koehler \& Mishra, 2009), their attitude towards ICT (Anderson \& Maninger, 2007; Bas, Kubiatko, \& Murat, 2016), their attention to special education and health concerning ICT (Akbulut, 2009), their self-efficacy in ICT use (Kreijns, Van Acker, Vermeulen, \& Van Buuren, 2013; Rohatgi, Scherer, \& Hatlevik, 2016), their beliefs regarding the use of technologies (Bas et al., 2016), their type of use of technology (Bai, Moo, Zhang, Boswell, \& Rozelle, 2016), their methodological ideas that are aligned with constructivism (Koehler \& Mishra, 2005; Petko, 2012; Prestridge, 2012), and their coordinated efforts with one another at the centre to incorporate and use ICT (Bingimlas, 2009; Tondeur et al., 2008; Wong \& Li, 2008). Abbitt and Klett (2007) affirm that the level of interest in computer technology represents $41 \%$ of the variance in teacher feelings of self-efficacy in incorporating technology. In addition, Van Braak (2001) warns that while positive attitudes towards technology may affect the incorporation of ICT into the classroom, their effect is mediated by the capacity for technological innovativeness, which he considers the predictor with the greatest explanatory power. Akbulut et al. (2007) state that content and pedagogy are considered the most important 
aspects to infuse technology in the classroom. They agree with Hennessy, Ruthven, and Brindley (2005) when they state that teachers must develop and implement new strategies to mediate ICT-assisted instruction.

Other studies have focused on students. These studies identify learning style, analytic intelligence, sex, socioeconomic status, and parent attitudes towards ICT as the primary variables linked to ICT use (Aesaert \& van Braak, 2015; Aesaert et al., 2015). It seems that female students of the highest socioeconomic status use ICT most, particularly those whose mothers are highly educated. Based on the research of Van den Beemt and Diepstraten (2016), the influence of siblings and friends is another important factor. These authors argue that students are more or less inclined to use ICT according to the degree that their siblings and friends use ICT, including during leisure. They highlight the idea that to successfully incorporate ICT teachers should exploit the educational potential of the social networks that so powerfully hold young people's attention. The idea of the influence of ICT use as a leisure activity is also emphasized by Rohatgi et al. (2016), who claim that students' use of ICT for recreational purposes is the dominant predictor of ICT self-efficacy.

Regarding the relationship between ICT use and academic achievement, the literature does not provide consistent results. In certain studies, this relationship is not significant (Angrist \& Lavy, 2002; Erdogdu \& Erdogdu, 2015; Goolsbee \& Guryan, 2006; Leuven, Lindahl, Oosterbeek, \& Webbink, 2007; Skryabin, Zhang, Liu, \& Zhang, 2015). In contrast, other studies identify relationships between the two variables, although these relationships are relatively scarce (Banerjee, Cole, Duflo, \& Linden, 2007; Machin, McNally, \& Silva, 2007).

In assessing the obstacles to incorporating ICT in schools, the literature has identified several factors at the school and teacher levels, which were mentioned in the previous paragraphs. To these factors are added several factors derived from Education Administration policies. The primary barriers relate to the lack of infrastructure (hardware and software), the lack of digital competency among teachers, resistance to the changes that ICT incorporation involves, the ineffectiveness of teacher training, the lack of time in the school bureaucracy to learn to teach with ICT, and the lack of technical support staff who can help the teachers (Bingimlas, 2009; Inan \& Lowther, 2010; Unal \& Ozturk, 2012).

Numerous studies consider teachers and their attitudes, concepts, or practices to be factors in the incorporation of ICT into the classroom that possess much greater weight than other factors (Akbulut et al., 2007; Drent \& Meelissen, 2008; Koh \& Chai, 2014; Lee \& Lee, 2014; Prestridge, 2012; Tondeur et al., 2008; Valtonen et al., 2015). Therefore, researchers propose to focus efforts on developing teacher training. This training would not simply increase levels of ICT competency, which represents the typical goal (Gillen, Staarman, Littleton, Mercer, \& Twiner, 2007; Hennessy, Deaney, Ruthven, \& Winterbottom, 2007), but also compel teachers to perceive and experience the advantages of innovative ICT use that orients the teaching and learning process towards the student. In this context, the teacher plays the role of directing learning while sharing ideas and experiences with other teachers involved in ICT introduction, in the style of collaborative communities. Specifically, Lee and Lee (2014) speak of encouraging the self-efficacy beliefs of teachers with respect to technology integration (SETI), teacher attitudes towards computers (TAC), computer use, lesson-planning skills, knowledge for effective technology integration, and instructional media development skills.

\section{Research framework and research questions}

This study analyses variables associated with the frequency with which secondary-school students use ICT in the course of their classroom activities. As explained in the previous section, at the school level, the scarcity or inadequacy of the ICT infrastructure has been the principal obstacle to incorporating ICT into teaching (Bingimlas, 2009; Pelgrum, 2001). At the teacher level, variables related to training, attitudes, concepts, and teaching activities have been identified. However, from the perspective of the teachers themselves, "it is equipment that is still the biggest obstacle to the use of ICT, followed by pedagogical factors" (European Commission, 2013, p. 71). It is obvious that the availability of resources is a prerequisite. However, we believe that resource availability alone is an insufficient explanation. The Unified Theory of Acceptance \& Use of Technology (Venkatesh, Morris, Davis, \& Davis, 2003) includes facilitating conditions among the constructs with a significant role as direct determinants of user acceptance and usage of technology. Specifically, facilitating conditions, which are understood as the belief that an organizational and technical infrastructure exists to support the use of technology, do not have a significant influence on behavioral intention, although their influence on the use of technology is stronger for older workers, particularly older workers with more experience (Venkatesh et al., 2003). The Concerns-Based Adoption Model (Hall \& Hord, 2015) has stated that each person will respond to a new program or innovation in accordance with their attitudes and beliefs, so the successful implementation of a new program involves more than providing materials or resources. According to the Technology Adoption Model, the perceived usefulness and the perceived ease of use are the factors that influence the acceptance and use of a technology (Davis, 1989). Based on these theories, our hypothesis is that in explaining ICT use in Spanish secondary-school classrooms, teacher characteristics are a more significant factor than resource availability.

The TALIS 2013 data provide measurements of classroom ICT use, school ICT equipment, and teacher characteristics, including ICT training needs, self-efficacy, professional collaboration, and teaching concepts. These elements were selected for this study because of their relationship to classroom ICT use as established in the literature. Therefore, we consider variables at the teacher level and at the school level. We control for teacher demographic characteristics with the aim of focusing attention on the relationship of classroom ICT use to ICT infrastructure and to teacher characteristics related to their teaching concepts and teaching performance. In contrast to demographic traits, these characteristics are more receptive from the perspective of education policy to interventions designed to promote classroom ICT. Specifically, our research questions are as follows:

a) Does a relationship exist between ICT infrastructure (i.e., computers, internet access and software) available in Spanish secondary schools and teacher ICT use in the classroom?

b) After controlling for the effects of teacher demographic traits and for available ICT infrastructure, are teacher characteristics with respect to teaching performance (i.e., professional development needs, efficacy, teacher collaboration and beliefs regarding teaching and learning) linked to ICT use in secondaryschool classrooms?

The conceptual framework developed for this study (Fig. 1) establishes that the use of ICT in classrooms is a function of school and teacher characteristics. The broken lines in the conceptual framework indicate control variables, while the solid lines reflect the relationships of interest in the study.

As explained in the introduction, the elements included in this conceptual framework have been examined in prior studies. However, in analysing the relationships that have been considered, studies that use broad representative samples at the national level and that simultaneously consider teacher- and school-related 


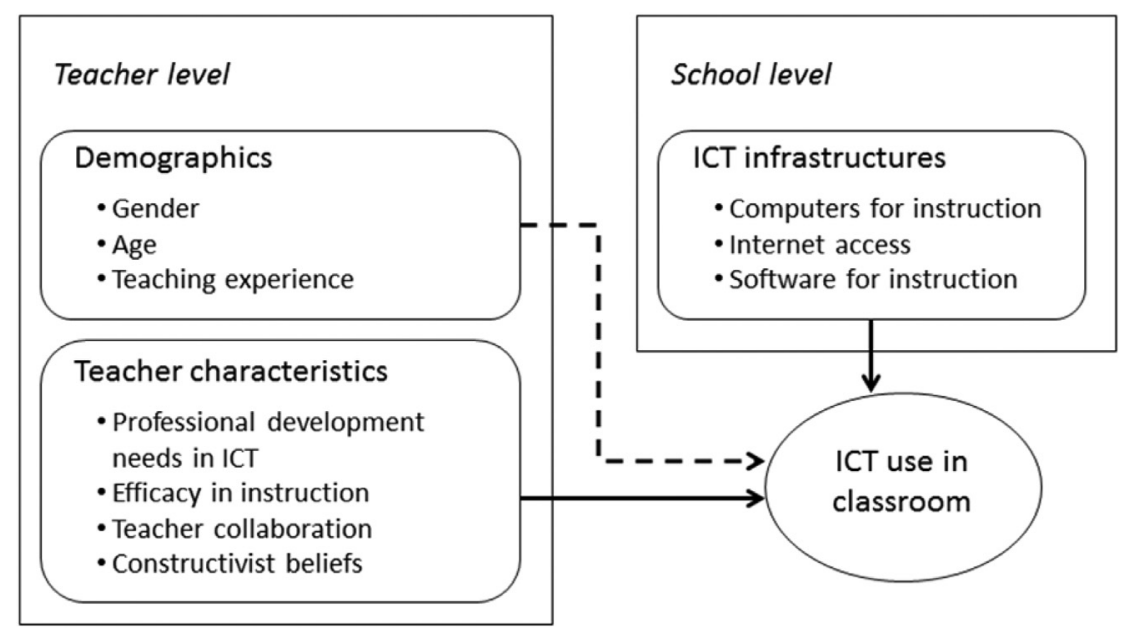

Fig. 1. Research framework.

variables are less common. In the case of secondary education in the Spanish educational system-the context of our study-we have not found similar studies.

\section{Method}

This study is a secondary analysis that uses data obtained in the TALIS 2013 study conducted by the OECD. The study is based on surveys of representative samples of teachers in 34 countries, including Spain. It aims to obtain international indicators and analysis regarding teachers and education, which can provide a basis for the review and development of policies that promote improvements in teaching and learning (OECD, 2013).

\subsection{Participants}

We considered the Spanish sample of teachers of compulsory secondary education (ISCED-2 level in the International Standard Classification of Education) who participated in TALIS 2013. This sample consists of 3339 teachers from 192 schools. In the case of Spain, the method used for their selection was stratified random sampling in the country's 18 autonomous communities. In each community, a certain number of schools were selected in proportion to the size of each stratum. Teachers were randomly chosen from within the 192 selected schools during the second stage of sampling.

\subsection{Variables}

A number of the variables selected for this study correspond to items from the questionnaires completed by teachers and school principals. Other variables are indices available in the TALIS 2013 database created based on scale analyses that used several items contained in the questionnaires. Scale scores for these indices are estimates of latent traits derived through scaling polytomous items using a latent-trait method (see OECD, 2014).

The dependent variable is ICT use in classroom. The information was provided by teachers, who indicated the frequency with which their students used ICT to complete projects or classwork. The answers of the teachers were originally expressed using a fourpoint scale ("never or nearly never," "occasionally," "frequently," or "in all or nearly all lessons"). For the analysis, the two lower levels and the two higher levels of the scale were grouped to create a binary variable with the following categories: 0 for "low use" and
1 for "high use."

Regarding independent variables, the first group includes the demographic traits of the teachers: teacher gender (male or female), age and teaching experience (number of years).

A second group of variables provides information regarding the ICT infrastructure in education centres: computers for instruction, internet access and software for instruction. These three variables, measured for each school, correspond to other items on the questionnaires answered by school principals, who described the degree to which the lack, insufficiency, or inadequacy of such infrastructure prevented their schools from offering quality instruction. The responses to these items were divided into two categories for each variable: 0 for "not a problem" and 1 for "a problem."

Last, the third group of variables corresponds to teacher characteristics that are related to training needs, concepts, and teaching performance. One of these variables gathers information on their needs for professional development in ICT. The data were obtained using an item in which teachers expressed the degree to which they required training in ICT skills that could be applied to instruction. The two categories for this variable were 0 for "no need or low level of need" and 1 for "moderate or high level of need." Together with training needs, we considered scores for three indices regarding the concepts, attitudes and practices of teachers, offered on the basis of TALIS data. These scales were constructed using confirmatory factor analysis based on questionnaire items (see OECD, 2014). For these items, the scores are expressed on a scale with a standard deviation of 2 , with a 10 score coinciding with the midpoint of the response scale for the items that are the basis for its construction. The three indices are as follows:

\subsubsection{Efficacy in instruction}

Measured using four items that indicate the degree to which the teacher is capable of implementing specific educational activities (e.g., "Implement alternative instructional strategies in my classroom"). The four items were measured on a four-point scale, with response categories of 1 for "not at all," 2 for "to some extent," 3 for "quite a bit," and 4 for "a lot."

\subsubsection{Teacher collaboration}

The four items used to create this index collect information on the frequency with which the teacher implements specific activities in collaboration with other teachers (e.g., "Teach jointly as a team in the same class"). The items were measured on a six-point 
scale. The response categories were 1 for "never," 2 for "once a year or less," 3 for "2-4 times a year," 4 for " $5-10$ times a year," 5 for "1-3 times a month," and 6 for "once a week or more."

\subsubsection{Constructivist beliefs}

The index was measured by four items administered to teachers. These items gather information regarding the degree to which teachers agree or disagree with certain statements on teaching (e.g., "Students should be allowed to think of solutions to practical problems themselves before the teacher shows them how they are solved"). The items were answered on a four-point scale, with response categories of 1 for "strongly disagree," 2 for "disagree," 3 for "agree," and 4 for "strongly agree."

Table 1 contains a list of the variables considered in the study, including descriptive statistics. In the case of the continuous variables, medians and standard deviations are listed, while percentages are listed for categorical variables.

\subsection{Data analysis}

We adopt logistic regression models to analyse the relationship between the independent variables and classroom ICT use. Considering that teachers are embedded in schools, the responses of teachers from within a single school are not independent from one another because these teachers are based in the same school context. Therefore, we used a multilevel model to conduct a single analysis with variables measured on the teacher level (Level 1) and the school level (Level 2). The two-level random intercepts logistic model considers the dependent variable ICT use in the classroom to present a binomial distribution with parameters of 1 and $\pi_{\mathrm{ij}}$, and its variance is $\pi_{\mathrm{ij}}\left(1-\pi_{\mathrm{ij}}\right)$, where $\pi_{\mathrm{ij}}$ is the probability that ICTs are frequently used in teacher i's class in school $\mathrm{j}$. Considering fixed effects for the explanatory variables in both groups, the logit model assumes the following form:

$\operatorname{logit}\left(\pi_{i j}\right)=\beta_{0}+\sum_{k=1}^{K} \beta_{k} X_{k i j}+\sum_{h=1}^{H} \beta_{h} Z_{h j}+\mu_{0 j}$

where $\mathrm{X}_{\mathrm{kij}}$ denotes the $\mathrm{K}$ explanatory variables measured on the teacher level and $Z_{h j}$ denotes the $H$ variables measured on the school level. The intercept consists of a fixed component $\beta_{0}$ and a school-specific component: the random effect $\mathrm{u}_{0 \mathrm{j}}$. We assume that $\beta_{0}$ and $\mathrm{u}_{0 \mathrm{j}}$ follow a normal distribution with means of zero and variances of $\sigma_{\mu 0}^{2}$.

The odds-ratios are calculated using the $\beta$ coefficients obtained for the multilevel logistic regression model. These indicate changes in the probabilities of frequent ICT use in classrooms for a 1-unit increase in the explicative variable $\mathrm{X}$. For binary variables, the odds ratio compares the odds for units with $\mathrm{X}=1$ with the odds for units with $\mathrm{X}=0$.

Using the MLwiN 2.35 program, we constructed four regression models to address the stated research questions: (I) the null or unconditional model; (II) the control model, adjusted for the gender, age, and teaching experience variables; (III) the ICT infrastructure model, which is constructed using the control model and includes the computers for instruction, internet access, and software for instruction variables; and (IV) the teacher characteristics model, which is constructed using the ICT infrastructure model and includes the needs for professional development in ICT, efficacy in instruction, teacher collaboration, and constructivist beliefs variables. The parameters were obtained using penalized quasi-likelihood estimation (PQL). The Wald $\chi^{2}$ test was used to determine the significance of the terms added to the model, considered jointly, and to separately determine the significance of each of the $\beta$ coefficients.

\section{Results}

Table 2 presents the results obtained for the successive multilevel logistic regression models. According to Model I, in which predictor variables for Level 1 (teachers) and Level 2 (schools) were not included, classroom ICT use varies significantly between schools $\left(\sigma_{\mu 0}^{2}=0.381, \chi^{2}=29.082, \mathrm{df}=1, \mathrm{p}<0.001\right)$. If we bear in mind that residual variation within each school is $\pi^{2} / 3=3.29$, the variability between schools is $(0.381 /(0.381+3.29))=0.104$, that is, $10.4 \%$ of the total variability. Therefore, there is a significant school effect independent of explanatory variables that affects the use of ICT in classrooms and makes the adoption of a multilevel model advisable.

Model II was constructed by incorporating the fixed effects of the demographic variables measured on the teacher level into the unconditional model, with the aim of controlling for their effect on subsequent, more developed models. The analysis of the Model II results reveals significant effects of the variables for gender

Table 1

Variables and descriptive statistics.

\begin{tabular}{|c|c|c|}
\hline Variable & Coding & Descriptive statistics \\
\hline \multicolumn{3}{|l|}{ Teacher level } \\
\hline \multirow[t]{2}{*}{ Gender } & $0=$ Female & $59.1 \%$ \\
\hline & $1=$ Male & $40.9 \%$ \\
\hline Age & Continuous & $\mathrm{M}=45.5 ; \mathrm{SD}=8.57$ \\
\hline Teaching experience: number of years & Continuous & $M=18.1 ; S D=9.47$ \\
\hline \multirow[t]{2}{*}{ ICT use in classroom } & $0=$ low use & $62.9 \%$ \\
\hline & $1=$ high use & $37.1 \%$ \\
\hline \multirow[t]{2}{*}{ Needs for professional development in ICT } & $0=$ No need of low level & $34.4 \%$ \\
\hline & $1=$ Moderate or high level & $65.6 \%$ \\
\hline Efficacy in instruction & Continuous & $M=12.6 ; S D=1.64$ \\
\hline Teacher collaboration & Continuous & $\mathrm{M}=6.4 ; \mathrm{SD}=1.53$ \\
\hline Constructivist beliefs & Continuous & $\mathrm{M}=12.5 ; \mathrm{SD}=2.16$ \\
\hline \multicolumn{3}{|l|}{ School level } \\
\hline \multirow[t]{2}{*}{ Computers for instruction } & $0=$ Not a problem & $64.7 \%$ \\
\hline & $1=$ A problem & $35.3 \%$ \\
\hline \multirow[t]{2}{*}{ Internet access } & $0=$ Not a problem & $66.5 \%$ \\
\hline & $1=\mathrm{A}$ problem & $33.5 \%$ \\
\hline \multirow[t]{2}{*}{ Software for instruction } & $0=$ Not a problem & $58.0 \%$ \\
\hline & $1=$ A problem & $42.0 \%$ \\
\hline
\end{tabular}

$\mathrm{M}=$ mean. $\mathrm{SD}=$ standard deviation. 
Table 2

Multilevel logistic regression results (dependent variable: ICT use in classroom).

\begin{tabular}{|c|c|c|c|c|c|c|c|c|}
\hline & \multicolumn{2}{|l|}{ Model I } & \multicolumn{2}{|l|}{ Model II } & \multicolumn{2}{|l|}{ Model III } & \multicolumn{2}{|l|}{ Model IV } \\
\hline & $\beta$ & SE & $\beta$ & SE & $\beta$ & SE & $\beta$ & SE \\
\hline \multicolumn{9}{|l|}{ Effects } \\
\hline Intercept & $-0.561^{* * *}$ & 0.060 & $-0.985^{* *}$ & 0.303 & $-0.330^{* *}$ & 0.118 & $-3.848^{* * *}$ & 0.440 \\
\hline Gender $^{\mathrm{a}}$ & & & $0.174^{*}$ & 0.082 & $0.174^{*}$ & 0.082 & 0.147 & 0.086 \\
\hline Age & & & 0.016 & 0.009 & & & & \\
\hline Teaching experience & & & $-0.022^{* *}$ & 0.008 & $-0.009^{*}$ & 0.004 & -0.005 & 0.005 \\
\hline Computers ${ }^{b}$ & & & & & -0.147 & 0.166 & & \\
\hline Internet access ${ }^{\mathrm{b}}$ & & & & & 0.108 & 0.162 & & \\
\hline Software ${ }^{b}$ & & & & & $-0.299^{*}$ & 0.145 & $-0.321^{* *}$ & 0.123 \\
\hline Needs for PD in $\mathrm{ICT}^{c}$ & & & & & & & $-0.487^{* * *}$ & 0.089 \\
\hline Efficacy in instruction & & & & & & & $0.153^{* * * *}$ & 0.027 \\
\hline Teacher collaboration & & & & & & & $0.166^{* * *}$ & 0.029 \\
\hline Constructivist beliefs & & & & & & & $0.059^{* *}$ & 0.020 \\
\hline Wald $\chi^{\mathrm{b}}(\mathrm{df})$ & & & $4.336(3)$ & & $8.118(3)$ & & $125.199(4$ & \\
\hline $\mathrm{p}$ value for contrast of terms (added to model) & & & 0.037 & & 0.044 & & 0.000 & \\
\hline School level var. (SE) & \multicolumn{2}{|l|}{$0.381^{* * *}(0.071)$} & \multicolumn{2}{|l|}{$0.389^{* * * *}(0.072)$} & \multicolumn{2}{|c|}{$0.358^{* * *}(0.069)$} & \multicolumn{2}{|c|}{$0.360^{* * *}(0.070)$} \\
\hline
\end{tabular}

${ }^{*} \mathrm{p}<0.05,{ }^{* *} \mathrm{p}<0.01,{ }^{* * *} \mathrm{p}<0.001$

a Reference category: "male".

b Reference category: "not a problem".

c Reference category: "no need or low level of need".

( $\beta=0.174, \mathrm{p}<0.05)$ and teaching experience $(\beta=-0.022, \mathrm{p}<0.01)$. That is, frequent use of ICT in classrooms is more likely among male teachers than female teachers. Years of experience have a negative effect, which involves diminishing classroom ICT use as the years of experience of the teachers increase. When these variables are considered, age does not correlate significantly with classroom ICT use by teachers. This variable was omitted in constructing the following model.

In Model III, the effect of the variables related to ICT infrastructure, considered jointly, was significant (Wald $\chi^{2}=8.118$, $\mathrm{df}=3, \mathrm{p}<0.05$ ). However, their incorporation into the regression model only results in a slight reduction in variance between schools that is not explained by the model $\left(\sigma^{2}{ }_{\mu 0}=0.358\right.$ versus $\sigma_{\mu 0}^{2}=0.381$ in the null model). If each of the variables is separately analysed, the effects of the availability of computers for teaching and of internet access are not significant, while the effect of educational software availability is significant $(\beta=-0.299$, $\mathrm{p}<0.05$ ). After controlling for the impact of gender and teaching experience, the frequent classroom ICT use by teachers is less likely when the availability and adaptation of educational software is a problem at the school.

Last, in Model IV, variables whose effects were not significant in the previous model were excluded, and variables measured at the teacher level, including training needs, ideas, and educational performance, were incorporated. The results obtained in adjusting Model IV clearly reveal significant effects for this new group of variables (Wald $\chi^{2}=125.199$, $\mathrm{df}=4, \mathrm{p}<0.001$ ). Considered individually, all of the incorporated variables relate to the use of ICT in classrooms. The frequent use of ICT in the classroom is associated with null or low professional development needs in ICT ( $\beta=-0.487, \mathrm{p}<0.001)$ and with high scores in the indices efficacy in instruction $(\beta=0.153, p<0.001)$, teacher collaboration $(\beta=0.166$, $\mathrm{p}<0.001)$ and constructivist beliefs $(\beta=0.059, \mathrm{p}<0.01)$. When these variables are considered, the effect of demographic characteristics is no longer significant.

The established regression model enabled the ranking of $67.2 \%$ of teachers. The precision or positive predictive value is $55.5 \%$, the negative predictive value is $75.5 \%$, the sensitivity or true positive rate is $60.6 \%$, and the specificity or true negative rate is $71.1 \%$. The Nagelkerke R-square value is 0.123 .

The odds-ratios were calculated using the coefficients estimated in the final model (Table 3). Their values indicate the degree to
Table 3

Crude and adjusted odds ratios (OR) and confidence intervals (95\% CI) for ICT use in classrooms, according to teacher and school variables included in the final model.

\begin{tabular}{lll}
\hline Variables & OR $(95 \% \mathrm{CI})$ & Adjusted OR $(95 \% \mathrm{CI})$ \\
\hline Gender & $1.17(1.00-1.36)$ & $1.16(0.98-1.37)$ \\
Teaching experience & $0.99(0.99-1.00)$ & $1.00(0.99-1.00)$ \\
Software & $0.71(0.61-0.83)$ & $0.73(0.57-0.92)$ \\
Needs for PD in ICT & $0.58(0.50-0.68)$ & $0.61(0.52-0.73)$ \\
Efficacy in instruction & $1.18(1.12-1.24)$ & $1.17(1.11-1.23)$ \\
Teacher collaboration & $1.22(1.16-1.29)$ & $1.18(1.12-1.25)$ \\
Constructivist beliefs & $1.08(1.04-1.12)$ & $1.06(1.02-1.10)$ \\
\hline
\end{tabular}

which frequent classroom ICT use is more or less probable when the reference value is modified or when the value of the explanatory variables is increased. Among the teacher characteristics, the two most significant are the need for ICT training and collaboration among teachers. The probability of frequent ICT use by teachers who need ICT training at moderate to high levels diminishes by $39 \%$ compared with those who have null or low levels (oddsratio $=0.61$ ). In contrast, the probability of frequent classroom ICT use increased by $18 \%$ with each unit increase in the index for teacher collaboration (odds-ratio $=1.18$ ). Situations arise in Spanish schools in which both variables are unfavourable. According to the descriptive statistics shown in Table 1, a significant percentage of Spanish teachers (65.6\%) describe moderate to high ICT training needs, and collaboration among teachers is the teacher-related characteristic with the lowest index number (6.4). At the school level, when a teacher works in a school in which software availability is a problem, the probability of using ICT is reduced by $27 \%$ compared with schools in which software availability is not a problem.

\section{Discussion and conclusions}

Using the first of the research questions presented in this study as a reference, we can affirm similarly to other authors (Aoki, Kim, \& Lee, 2013; Bingimlas, 2009; De Witte \& Rogge, 2014; Lee, 2002) that infrastructure represents a necessary but not a sufficient condition for the integration of ICT into the classroom. Access to such infrastructure is an obvious prerequisite to being able to use ICT. However, greater or lesser amounts of ICT infrastructure in 
schools are not generally related to the frequency of classroom use. If we differentiate between infrastructure types, it is necessary to note certain nuances. The variables computers for instruction and internet access do not display a statistically significant relationship with the dependent variable. In contrast, software for instruction exhibits significant effects, which increases the probability of frequent use of ICT in schools in which appropriate educational software is available. These results confirm the importance attributed in the literature to the availability of software compared with hardware (Bingimlas, 2009; Lee, 2002).

Regarding the second research question, our results indicate a relationship between classroom ICT use and teacher characteristics, such as the need for ICT training, collaboration among teachers, perceived self-efficacy, and teaching concepts. When these variables are considered, demographic traits (gender, age and teaching experience) turn out to be irrelevant in explaining ICT use.

At the teacher level, need for professional development in ICT is the most significant variable in explaining classroom ICT use. Moderate or high training needs perceived by teachers are associated with a lower probability of frequent ICT use. This result is compatible with the findings of previous studies, which have noted links between the level of ICT integration in teaching and variables such as ICT competency or participation in ICT-related professional development activities (Bingimlas, 2009; Van Braak, 2001; Vanderlinde, Aesaert, \& van Braak, 2014). The role of the teacher's perceived self-efficacy was highlighted in previous studies, in which self-efficacy was associated with the incorporation of technology into teaching (Lee \& Lee, 2014) or with the use of digital learning materials (Kreijns et al., 2013). Constructivist beliefs also relate to the use of ICT in schools. This study's results indicate an increase in the probability of frequent ICT use when teachers adopt these ideas. Wong and Li (2008) highlight the importance of constructivist concepts and collaboration between teachers, together with other variables such as leadership, school climate, government ICT policy, ICT infrastructure, and ICT competency. This outcome agrees with the results of other studies (Ertmer, 2005; Koehler \& Mishra, 2005; Mama \& Hennessy, 2013; Petko, 2012; Prestridge, 2012; Tondeur et al., 2008).

This study has enabled us to confirm that teacher characteristics are more relevant than the availability of ICT infrastructure in explaining ICT use in Spanish centres of secondary education. The amount of ICT infrastructure in Spanish schools is high. In fact, it is among the highest in Europe. However, infrastructure alone is not enough. The use of ICT in classrooms is limited by teacher characteristics, particularly because of the high ICT training needs of teachers and low levels of collaboration among teachers. Using this information, interventions should be created to encourage the use of ICT in Spanish schools.

As Meneses et al. (2014), initiatives developed to evaluate ICT penetration in the Spanish educational system have exclusively focused on numbers of computers and the quality of internet connections. Thus, important factors have been neglected. According to our results, the availability of appropriate software and proper teacher training are key components in achieving true ICT integration. According to the recommendations of various authors (Bingimlas, 2009; Drent \& Meelissen, 2008; Koh \& Chai, 2014; Lee \& Lee, 2014; Valtonen et al., 2015), teacher training should focus on having teachers master technological pedagogical content knowledge and effectively incorporating that knowledge as they develop the teaching and learning processes that occur in the classroom. To achieve this goal, these training proposals must be directed at teams of teachers who work in the same school (Vanderlinde et al., 2014 ) to encourage professional collaboration, develop teacher selfefficacy, and encourage the acceptance of teaching concepts with a constructivist focus.
For these changes to be feasible at the teacher or faculty level, it is necessary for education policies and school leadership to promote new ways of teaching and learning, to support teacher development of ICT skills and ICT-supported pedagogical skills, and to create a collaborative school culture that supports ICT implementation (Pelgrum \& Voogt, 2009). Additionally, it is necessary to develop mechanisms for sharing and distributing research, promising policies, and practices with respect to ICT in education and to nurture an international community of ICT scholars, policymakers, and leaders who continually build on the knowledge base to inform policy and practice (Voogt, Knezek, Cox, Knezek, \& ten Brummelhuis, 2013).

As stated previously, the practical implications of the results of this study indicate the need to supplement the investment in ICT infrastructure with other measures. Specifically, educational policies should increase the investment in teacher training, their professional development in ICT and the creation and dissemination of quality educational software for classroom use. In this sense, it would be worthwhile to encourage new pathways for teachers' professional development based on modalities such as online teacher learning communities, blended learning, "on the job" training, and peer learning and peer sharing activities at school. Furthermore, the development of the ICT competency of teachers should have a prominent place in initial teacher training by promoting skills acquisition for ICT use in the classroom and developing positive attitudes towards the value of ICT in teaching. At the level of educational institutions, time should be allocated for teacher collaboration, the shared reflection on experiences regarding the use of ICT in teaching and learning and the joint assessment, selection and adaption of digital learning resources. These measures may have an impact on schools, teachers and students. The idea is to develop a school culture that favours the integration of ICT into education, increased teacher competence and confidence in the use of ICT, which results in the greater use of ICT in classrooms and contributes to students' improved motivation, learning and digital literacy.

In closing, we highlight several of our study's strengths and weaknesses. In conducting a secondary analysis of the data from the TALIS study, we had access to a broad, representative sample of Spanish secondary-education teachers through data obtained through rigorous survey procedures. However, this approach entails several limitations. Because the data consist of self-reports by teachers, variable measurements are mediated by teacher perceptions. Regarding the dependent variable, the frequency of ICT in the classroom was considered according to the information that was provided by teachers. However, it would have been interesting to contrast this information with information obtained from other sources, such as students, for example. Additionally, our study has only used variables available in the TALIS database. Because TALIS was not a study specifically directed at the use of ICT in education, we were unable to analyse other teacher characteristics as independent variables. In future studies, it would be interesting to include teacher-related variables more closely focused on ICT use. Characteristics that could be considered include beliefs regarding technology, attitudes or predispositions towards technology, selfefficacy in ICT-based teaching, collaboration among teachers in ICT-supported teaching and learning processes, or the capacity for planning classes using ICT. A further limitation is associated with the methodological approach that was used. The logistic regression made it possible to analyse the relationship between many independent variables and the frequency of ICT use in the classroom. However, the correlation that was found does not imply causality among the variables. Future research that adopts experimental designs may help to contrast the possible effects of certain interventions (e.g., based on the software availability for teaching or 
on teachers' professional development in ICT) on the integration of ICT into classrooms.

\section{References}

Abbitt, J. T., \& Klett, M. D. (2007). Identifying influences on attitudes and selfefficacy beliefs towards technology integration among pre-service educators. Electronic Journal for the Integration of Technology in Education, 6(1), 28-42.

Aesaert, K., \& van Braak, J. (2015). Gender and socioeconomic related differences in performance based ICT competences. Computers \& Education, 84, 8-25. http:/ dx.doi.org/10.1016/j.compedu.2014.12.017.

Aesaert, K., van Nijlen, D., Vanderlinde, R., Tondeur, J., Devlieger, I., \& van Braak, J. (2015). The contribution of pupil, classroom and school level characteristics to primary school pupils' ICT competences: A performance-based approach. Computers \& Education, 87, 55-69. http://dx.doi.org/10.1016/ j.compedu.2015.03.014.

Akbulut, Y. (2009). Investigating underlying components of the ICT Indicators measurement scale: The extended version. Journal of Educational Computing Research, 40(4), 405-427. http://dx.doi.org/10.2190/EC.40.4.b.

Akbulut, Y., Kesim, M., \& Odabasi, H. F. (2007). Construct validation of ICT indicators measurement scale (ICTIMS). The International Journal of Education and Development using Information and Communication Technology (IJEDICT), 3(3), 60-77.

Anderson, S. E., \& Maninger, R. M. (2007). Preservice teachers' abilities, beliefs, and intentions regarding technology integration. Journal of Educational Computing Research, 37(2), 151-172.

Angrist, J., \& Lavy, V. (2002). New evidence on classroom computers and pupil learning. The Economic Journal, 112(482), 735-765. http://dx.doi.org/10.1111/ 1468-0297.00068.

Aoki, H., Kim, J., \& Lee, W. (2013). Propagation \& level: Factors influencing in the ICT composite index at the school level. Computers \& Education, 60(1), 310-324. http://dx.doi.org/10.1016/j.compedu.2012.07.013.

Area, M., Alonso, C., Correa, J. M., del Moral, M. E., de Pablos, J., Paredes, J., ... Valverde, J. (2014). ICT education policies in Spain after school program 2.0: Emerging trends. RELATEC Revista Latinoamericana de Tecnología Educativa, 13(2), 11-33.

Bai, Y., Moo, D., Zhang, L., Boswell, M., \& Rozelle, S. (2016). The impact of integrating ICT with teaching: Evidence from a randomized controlled trial in rural schools in China. Computers \& Education, 96, 1-14. http://dx.doi.org/10.1016/ j.compedu.2016.02.005.

Banerjee, A. S., Cole, S., Duflo, E., \& Linden, L. (2007). Remedying education: Evidence from two randomized experiments in India. Quarterly Journal of Economics, 122(3), 1235-1264. http://dx.doi.org/10.1162/ajec.122.3.1235.

Bas, G., Kubiatko, M., \& Murat, A. (2016). Teachers' perceptions towards ICTs in teaching-learning process: Scale validity and reliability study. Computers in Human Behavior, 61, 176-185. http://dx.doi.org/10.1016/j.chb.2016.03.022.

Bingimlas, K. A. (2009). Barriers to the successful integration of ICT in teaching and learning environments: A review of the literature. Eurasia Journal of Mathematics, Science \& Technology Education, 5(3), 235-245.

Davis, F. D. (1989). Perceived usefulness, perceived ease of use, and user acceptance of information technology. MIS Quarterly, 13(3), 319-340.

De Witte, K., \& Rogge, N. (2014). Does ICT matter for effectiveness and efficiency in mathematics education? Computers \& Education, 75, 173-184. http://dx.doi.org/ 10.1016/j.compedu.2014.02.012.

Drent, M., \& Meelissen, M. (2008). Which factors obstruct or stimulate teacher educators to use ICT innovatively? Computers \& Education, 51(1), 187-199. http://dx.doi.org/10.1016/j.compedu.2007.05.001.

Eng, T. S. (2005). The impact of ICT on learning: A review of research. International Education Journal, 6(5), 635-650.

Erdogdu, F., \& Erdogdu, E. (2015). The impact of access to ICT, student background and school/home environment on academic success of students in Turkey: An international comparative analysis. Computers \& Education, 82, 26-49. http:// dx.doi.org/10.1016/j.compedu.2014.10.023.

Ertmer, P. A. (2005). Teacher pedagogical beliefs: The final frontier in our quest for technology integration? Educational Technology Research and Development, 53(4), 25-39. http://dx.doi.org/10.1007/BF02504683.

Ertmer, P., Ottenbreit-Leftwich, A., \& York, C. (2007). Exemplary technology use: Teachers' perceptions of critical factors. Journal of Computing in Teacher Education, 23(2), 55-61.

European Commission. (2013). Survey of schools: ICT in education. Retrieved from https://ec.europa.eu/digital-agenda/node/51275.

Fraizer, M., \& Bailey, G. (2004). The technologys coordinator's handbook. Londres: ISTE.

Gillen, J., Staarman, J., Littleton, K., Mercer, N., \& Twiner, A. (2007). A 'learning revolution'? Investigating pedagogic practice around interactive whiteboards in British primary classrooms. Learning, Media and Technology, 32(3), 243-256.

Goolsbee, A., \& Guryan, J. (2006). The impact of internet subsidies in public schools. The Review of Economics and Statistics, 88(2), 336-347. http://dx.doi.org/ 10.1162/rest.88.2.336.

Hall, G. E., \& Hord, S. M. (2015). Implementing change: Patterns, principles and potholes (4th ed.). Upper Saddle River, NJ: Pearson.

Hennessy, S., Deaney, R., Ruthven, K., \& Winterbottom, M. (2007). Pedagogical strategies for using the interactive whiteboard to foster learner participation in school science. Special Issue of Learning Media and Technology on Interactive
Whiteboards, 32(3), 283-301

Hennessy, S., Ruthven, K., \& Brindley, S. (2005). Teacher perspectives on integrating ICT into subject teaching: Commitment, constraints, caution and change. Journal of Curriculum Studies, 37(2), 155-192. http://dx.doi.org/10.1080/ 0022027032000276961.

Inan, F. A., \& Lowther, D. L. (2010). Factors affecting technology integration in K-12 classrooms: A path model. Educational Technology Research and Development 58(2), 137-154.

NE. (2014). Tecnologías de la información en la enseñanza no universitaria: Principales resultados anuales, Serie 2002-2014 [Information technology in non-university teaching: Primary annual results, Serie 2002-2014]. Madrid: INE.

Koehler, M. J., \& Mishra, P. (2005). Teachers learning technology by design. Journal of Computing in Teacher Education, 21(3), 94-102.

Koehler, M. J., \& Mishra, P. (2009). What is technological pedagogical content knowledge (TPACK)? Contemporary Issues in Technology and Teacher Education, 9(1), 60-70.

Koh, J. H. L., \& Chai, C. S. (2014). Teacher clusters and their perceptions of technological pedagogical content knowledge (TPACK) development through ICT lesson design. Computers \& Education, 70, 222-232. http://dx.doi.org/10.1016/ j.compedu.2013.08.017.

Kreijns, K., Van Acker, F., Vermeulen, M., \& Van Buuren, H. (2013). What stimulates teachers to integrate ICT in their pedagogical practices? The use of digital learning materials in education. Computers in Human Behavior, 29(1), 217-225.

Lee, K. T. (2002). Effective teaching in the information era: Fostering an ICT-based integrated learning environment in schools. Asia-Pacific Journal for Teacher Education and Development, 5(1), 21-45.

Lee, Y., \& Lee, J. (2014). Enhancing pre-service teachers' self-efficacy beliefs for technology integration through lesson planning practice. Computers \& Education, 73, 121-128. http://dx.doi.org/10.1016/j.compedu.2014.01.001.

Leuven, E., Lindahl, M., Oosterbeek, H., \& Webbink, D. (2007). The effect of extra funding for disadvantaged pupils on achievement. The Review of Economics and Statistics, 89(4), 721-736. http://dx.doi.org/10.1162/rest.89.4.721.

Machin, S., McNally, S., \& Silva, O. (2007). New technology in Schools: Is there a payoff? Economic Journal, 117(522), 1145-1167. http://dx.doi.org/10.1111/j.14680297.2007.02070.x.

Mama, M., \& Hennessy, S. (2013). Developing a typology of teacher beliefs and practices concerning classroom use of ICT. Computers \& Education, 68, 380-387. http://dx.doi.org/10.1016/j.compedu.2013.05.022.

Meneses, J., Fàbregues, S., Jacovkis, J., \& Rodríguez-Gómez, D. (2014). The introduction of ICT in Spanish education (2000-2010): A comparative analysis of regional policies from a multi-level approach. Estudios Sobre Educación, 27, 63-90. http://dx.doi.org/10.15581/004.27.63-90.

OECD. (2013). Teaching and learning international survey TALIS 2013. Conceptual framework. Retrieved from http://www.oecd.org/edu/school/TALIS\% 20Conceptual\%20Framework_FINAL.pdf.

OECD. (2014). TALIS 2013 technical report. Retrieved from http://www.oecd.org/edu/ school/TALIS-technical-report-2013.pdf.

Pelgrum, W. J. (2001). Obstacles to the integration of ICT in education: Results from a worldwide educational assessment. Computers \& Education, 37, 163-178. http://dx.doi.org/10.1016/S0360-1315(01)00045-8.

Pelgrum, W. J., \& Voogt, J. (2009). School and teacher factors associated with frequency of ICT use by mathematics teachers: Country comparisons. Education and information technologies, 14(4), 293-308.

Petko, D. (2012). Teachers' pedagogical beliefs and their use of digital media in classrooms: Sharpening the focus of the "will, skill, tool" model and integrating teachers' constructivist orientations. Computers \& Education, 58(4), 1351-1359. http://dx.doi.org/10.1016/j.compedu.2011.12.013.

Prestridge, S. (2012). The beliefs behind the teacher that influences their ICT practices. Computers \& Education, 58(1), 449-458. http://dx.doi.org/10.1016 j.compedu.2011.08.028.

Rohatgi, A., Scherer, R., \& Hatlevik, O. E. (2016). The role of ICT self-efficacy for students' ICT use and their achievement in a computer and information literacy test. Computers \& Education, 102, 103-116. http://dx.doi.org/10.1016/ j.compedu.2016.08.001.

Scherer, R., Siddiq, F., \& Teo, T. (2015). Becoming more specific: Measuring and modeling teachers' perceived usefulness of ICT in the context of teaching and learning. Computers \& Education, 88, 202-214. http://dx.doi.org/10.1016/ j.compedu.2015.05.005.

Skryabin, M., Zhang, J., Liu, L., \& Zhang, D. (2015). How the ICT development level and usage influence student achievement in reading, mathematics, and science. Computers \& Education, 85, 49-58. http://dx.doi.org/10.1016 j.compedu.2015.02.004.

Suárez, J. M., Almerich, G., Orellana, N., \& Belloch, C. (2012). The use of ICTs by non university's faculty. Basic model and influence of personal and contextual factors. Revista Iberoamericana de Evaluación Educativa, 5(1), 249-265. Retrieved from http://www.rinace.net/riee/numeros/vol5-num1_e/art18.pdf.

Tallent-Runnels, M. K., Thomas, J. A., Lan, W. Y., Cooper, S., Ahern, T. C., Shaw, S. M. et al. (2006). Teaching courses online: A review of the research. Review of Educational Research, 76(1), 93-135. http://dx.doi.org/10.3102/ 00346543076001093.

Tondeur, J., Valcke, M., \& van Braak, J. (2008). A multidimensional approach to determinants of computer use in primary education: Teacher and school characteristics. Journal of Computer Assisted Learning, 24(6), 494-506.

Tondeur, J., van Braak, J., \& Valcke, M. (2007). Towards a typology of computer use in Primary Education. Journal of Computer Assisted Learning, 23(3), 197-206. 
http://dx.doi.org/10.1111/j.1365-2729.2006.00205.x.

Unal, S., \& Ozturk, I. H. (2012). Barriers to ITC integration into teachers' classroon practices: Lessons from a case study on social studies teachers in Turkey. World Applied Sciences Journal, 18(7), 939-944.

Vacchieri, A. (2013). Estado del arte sobre la gestión de las políticas de integración de computadoras y dispositivos móviles en los sistemas educativos [State of the art on the management of integration policies of computers and mobile devices into educational systems]. Argentina: UNICEF.

Valtonen, T., Kukkonen, J., Kontkanen, S., Sormunen, K., Dillon, P., \& Sointu, E. (2015) The impact of authentic learning experiences with ICT on pre-service teachers' intentions to use ICT for teaching and learning. Computers \& Education, 81, 49-58. http://dx.doi.org/10.1016/j.compedu.2014.09.008.

Van Braak, J. (2001). Individual characteristics influencing teachers' class use of computers. Journal of educational computing research, 25(2), 141-157.

Van Braak, J., Tondeur, J., \& Valcke, M. (2004). Explaining different types of computer use among primary school teachers. European Journal of Psychology of
Education, 19(4), 407-422

Van den Beemt, A., \& Diepstraten, I. (2016). Teacher perspectives on ICT: A learning ecology approach. Computers \& Education, 92, 161-170. http://dx.doi.org/ 10.1016/j.compedu.2015.10.017.

Vanderlinde, V., Aesaert, K., \& van Braak, J. (2014). Institutionalised ICT use in primary education: A multilevel analysis. Computers \& Education, 72, 1-10. http:// dx.doi.org/10.1016/j.compedu.2013.10.007.

Venkatesh, V., Morris, M. G., Davis, G. B., \& Davis, F. D. (2003). User acceptance of information technology: Toward a unified view. MIS Quartely, 27(3), 425-478.

Voogt, J., Knezek, G., Cox, M., Knezek, D., \& ten Brummelhuis, A. (2013). Under which conditions does ICT have a positive effect on teaching and learning? A call to action. Journal of computer assisted learning, 29(1), 4-14.

Wong, E. M., \& Li, S. C. (2008). Framing ICT implementation in a context of educational change: A multilevel analysis. School effectiveness and school improvement, 19(1), 99-120. http://dx.doi.org/10.1080/09243450801896809. 